\title{
Systematizing Policy LeARning: FROM MONOLITHS TO DIMENSIONS
}

\author{
Claire A. Dunlop and Claudio M. Radaelli
}

\begin{abstract}
The field of policy learning is characterised by a proliferation of concepts and lack of systematic findings. Our collation of studies of learning in the political science literature reveals the presence of many different dimensions and approaches. To systematize them, we combine the classic Sartorian approach to classification with the more recent insights on explanatory typology. At the outset, we classify per genus et differentiam - distinguishing between the genus and the different species within it. We then draw on the technique of explanatory typologies to introduce a basic model of policy learning, capturing the four major genera identified in the literature. We then generate variation within each cell by using rigorous concepts drawn from adult education research. Specifically, we conceptualize learning as control over the contents and goals of knowledge. By looking at learning through the lenses of knowledge utilization, we show that the basic model can be expanded to reveal sixteen different species. These types are all conceptually established in the literature, but up until now the scope conditions and connections among types have not been clarified. Our reconstruction of the field sheds light on mechanisms and relations associated with alternatives operationalizations of learning and the role of actors in the process of knowledge construction and utilization. By providing a comprehensive typology, we aim to lay the foundations for the systematic comparison across and within cases of policy learning.
\end{abstract}

Keywords: policy learning, typologies, concept formation 


\section{INTRODUCTION}

In this article, we critically reflect on the state of policy learning: there has been a proliferation of concepts and models, with the result that different strands of the literature, both in international relations and in political science, tend to talk past each other. We suggest a way forward by blending the classic Sartorian approach to classification with recent work on typologies in qualitative research (Sartori, 1970; Collier at al. 2008; Elman, 2005; George and Bennett 2005, chp.11). We build an explanatory typology that shows the connections and scope conditions for different forms of learning. Debates in this field resemble the classic ships crossing in the night because scholars have failed to sort out and clarify concepts, and the relationships between them. Our proposal revolves around the distinction between four major 'genera' of learning and the 'species' within each 'genus'.

At the outset, however, we have to define learning as updating of beliefs. In public policy, we are eminently concerned with beliefs about policies - whether it is the ideas that underpin them, their performance or the governance mechanisms and institutions of policymaking. This process of updating beliefs can be the result of social interaction, appraisals of one's experience (often of failure) or evidence-based analysis - or most likely a mix of the three. This minimal definition enables us to handle the entire literature we refer to in the remainder of the article.

There is renewed interest in policy learning, as shown by three special issues published in 2009 - two on diffusion and transfer (Dolowitz, 2009; Evans, 2009 respectively) and the third on the EU as learning organisation (Zito and Schout, 2009a). Further, some of the most popular frameworks developed since the early 1990s, such as policy transfer (Dolowitz and Marsh, 1996), the epistemic communities approach (Haas, 1992) and the advocacy coalitions framework (Sabatier and JenkinsSmith, 1993; Sabatier and Weible, 2007), have emerged from the attempt to generate theoretical propositions about learning in domestic and international policy domains.

Yet, even the most casual of observers would note that the field is struggling to produce cumulative knowledge on this topic. The analysis of learning - a classic topic since Deutsch (1966), 
Simon $(1947,1957)$ and, soon after, Heclo (1974) and Lindblom (1965, but see also the seminal work on muddling through, 1959) - has taken place within several self-contained sub-fields where there is empirical progress but relatively little interest in conversations across the discipline. At the same time, theoretical models (for example, Volden et al, 2008) have not as yet fully connected with the work of empirical analysts, perhaps with the exception of the field of policy diffusion (Graham et al, 2008; Meseguer, 2009; Weyland, 2005). The literature on governance has also added to the interest of the last fifteen years or so in re-discovering the analytical properties of learning, with emphasis on the organisational-institutional properties that generate learning outcomes (Eising, 2002; Olsen and Peters, 1996), the notion of experimentalist-democratic polyarchies (Gerstenberg and Sabel, 2002), varieties of principal-agent models (Author A, 2010, Author A and colleague, 2007; Waterman and Meier, 1998), epistemic structures in international governance regimes (Author A, 2009; Haas, 1992), and models of bargaining and mutual adjustment (Elgström and Jönsson, 2000). At the micro-level, researchers have worked on models of the mind, rationality and emotions, and how individuals get locked-in by persuasion, majority opinions, and other characteristics of group behaviour (Denzau and North, 1994).

Finally, international organisations are engaged in a debate with strong normative assumptions about how governments should learn. They have launched different instruments for cross-national and trans-national learning, such as benchmarking, peer review, checklists, and 'facilitated coordination' (Author B, 2004). Such normative concerns are refracted by academic studies on lesson-drawing (Rose, 1991), extrapolation (Barzelay, 2007), and benchmarking (Schäfer, 2006).

This intellectual activity is still very fluid, with limited cumulative knowledge (Author B, 2009). Recent reviews of the state of the art (Dobbin et al, 2007; Freeman, 2006; Grin and Loeber, 2007) contain only a handful of empirical studies, thus making it difficult to assess what we may collectively learn about this topic. This perhaps explains the general feeling of disappointment (Egan, 2009; James and Lodge, 2003; Volden et al., 2008). We still know little about how communities of policy-makers learn in real-world setting (Freeman, 2006, 2007). 
Thus, we need to step back a bit in order to sort out and systematize this intellectual activity and create the pre-conditions for cumulative knowledge. Interestingly, both Dolowitz (2009) and Boswell (2008) say we should focus on knowledge utilization to overcome some of the problems. We shall follow up on this suggestion. The article is organized step-by-step. In section one, we present a scattered plot of the literature. This plot does not make sense, because it provides some mind-boggling eleven dimensions of learning! Not all dimensions are on the same level of the ladder of abstraction: some are major themes in the literature, others are variations within the theme. By using the tools of concept formation and explanatory typologies (Sartori, 1970; Elman, 2005), in section two we separate the individual genus from the species within the genus. We build four genera by combining two variables - problem tractability and actor certification. Then, in section three, we expand the property space within each genus by considering the fundamental dimension of control over knowledge production (see Author A, 2009). Such 'expansion of the property space' (Elman, 2005) leads us to sixteen species of learning, and enables us to show the relationships between species and the conditions for one genus of learning and another. We conclude with a discussion of the usage of typologies and suggestions for future research.

\section{CONCEPTUALIZING POLICY LEARNING}

Learning has been examined in many different ways in public policy. By using different search options in the ISI social science citation index we identified some 833 articles from the main subfields of political science ${ }^{\mathrm{i}}$. After sifting these down to 86, we then added books and articles that are concerned with learning but do not show up in the social science citation index.

The first step in systematizing the field is to plot the articles on an n-dimensional space, where the n-dimensions are theoretically justified. This is not possible for a large majority of the articles, which belong to the 'null dimension' of not having any theoretical depth. True, some sources of theoretical inspiration are mentioned in the introduction - it is for example almost classic to find ‘evocations' of Peter Hall's three types of learning (1993) or of Haas's epistemic communities (1992). 
But essentially the study remains empirical, and evidence is not used for theory testing or theory building. This is not surprising since the whole landscape of policy analysis is still best described by few 'mountain islands of theoretical structure, intermingled with, and occasionally attached together by foothills of shared methods and concepts, and empirical work, all of which is surrounded by oceans of descriptive work not attached to any mountain of theory' (Schlager, 1997, p.14).

What about the papers with some theoretical depth, then? They do not fall neatly in any simple n-dimensional space - indeed, an ideal plot would look quite scattered. This is because the disciplinary orientation varies markedly, from international relations to public management. If we meander through the set of papers, we find several possible dimensions of theoretical spaces. Actually, potentially the set of articles generates no less than eleven dimensions, specifically:

(a) An epistemic dimension, where the learning process can be neatly captured by the asymmetry of information with the expert as teacher (Haas, 1992). This does not mean that the relationship between expert and policymaker runs smoothly, since there are political reasons why epistemic communities construct policy realities of cause and effect, but do not actually create them in the real world. But, overall, in epistemic communities model it is clear where expertise and policy-relevant knowledge are (i.e. the teacher).

(b) Epistemic actors, however, can facilitate learning but not contribute to the definition of the interests of the policymaker-learner (Author A, 2007; Lindquist, 1992, 1993). This is not the original model of epistemic communities, where given high uncertainty, interests cannot be defined by policy-makers, who draw on epistemic communities to reduce uncertainty and make sense of their preferences. This is a less radical model, with the experts that contributes to a learning process where the learner is in control of the goals and mode of knowledgeproduction (Author A, 2009).

(c) We then find a dimension that has yet again something to do with the epistemic teacher. Yet it differs profoundly because someone else (not the 'teacher') is in control of what and why should be learned. Indeed, in these articles, epistemic actors are no longer teachers. They are agents whose activities are shaped by policymakers as principals (Author A, 2010, Author A 
and colleague, 2007; Jordan and Greenaway, 1998; Rowe and Shepherd, 2002). This strand of research chimes with the work on advocacy think tanks, which in some cases enjoy autonomy from the principal, whilst in others can be classified as hired guns (Stone et al, 1998).

(d) The dimension of delegation, however, does not necessarily revolve around a relation between the expert and the policymaker. It is a self-contained lens on processes of power and regulation - indeed scholars working in this area do not make systematic references to the concept of epistemic communities. What matters in the delegation dimension is that knowledge production, utilization and diffusion are organized along a chain of delegation of tasks. Learning mechanisms are explained by different asymmetries of information and forms of oversight (Thatcher and Stone-Sweet, 2002; Waterman and Meier, 1998).

(e) A completely different approach breaks with the tradition of learning as a relation between a teacher and a pupil, and also with the principal-agent theorizations that see experts as hired guns or agents. This is the set of articles concerned with communities or networks of officers, elected politicians and civil society organizations that contribute collectively to the learning experience by exploring an issue, its meanings, and its political relevance. Richard Freeman (2006), for example, has drawn our attention on how communities and networks learn through deliberation, arguing that learning how is more important than learning that.

(f) Connected to this perspective, yet more oriented to purposeful action under conditions of manipulability of social representations is the dimension of issue framing, especially when there is an over-arching goal (Daviter, 2007; Grin and van De Graf, 1996).

(g) The experimental dimension amplifies some of the themes of issue framing and deliberative learning in networks. But here 'learning' is a broad category, almost synonymous of mode of governance (Lenoble and De Shutter, 2010; Sabel and Zeitlin, 2008). It covers experimental processes of trial-and-error with different forms of know-how and policy instruments, where Bayesian learning leads to the type of content that best fits a predefined preference (Moynihan, 2005). In turn, these processes lead to reflexive social learning (Sanderson, 2002, 2009) and discursive transformations of public policy (Fischer, 2003; Schmidt, 2002). 
(h) Yet another set of scholars sees learning as either intentional or, more often, un-intentional by-product of bargaining. Actors bargain to meet standards and targets. Sometimes they are in control of the goals and content of knowledge production. Sometimes they act under constraints. An example is provided by the conditionality literature - the literature has shown that 'smart' and 'clever' solutions are facilitated by the imperatives of conditionality (Weisband, 2000).

(i) Purposeful action can be more severely constrained when actors engage in learning and choose what to learn to deliver a pre-determined preference (Cram, 1993; Dolowitz, 1997; Grossback et al, 2004). The goals of knowledge production and utilization are entirely exogenous in this dimension and learning strategic.

(j) This leads us to another dimension of structured interaction among policymakers. Here there is a constellation of actors that perceive the need to make marginal improvement at the level of the tools of government and the instruments of public policy (Meseguer, 2005). What matters here is the scope of learning, rather than its modes. In fact, although the scope is limited, learning modes can be of different types, such as emulation, rational decoding of foreign experiences, or Bayesian learning. In this literature the major emphasis is on diffusion as outcome and learning as mechanism (of diffusion) (Gilardi, 2008; Meseguer, 2005, Meseguer and Escribà-Abel, 2011). Recent research in this field differentiates between the diffusion of instrumental learning (that is, learning about substantive policy improvement) and political learning (that is, learning about forms of policy change that are electorally rewarding) (Gilardi, 2010).

(k) Finally, we found a way of looking at learning in constellations of actors that interact in loosely-coupled organizations or policy arenas. It is difficult to predict how learning can occur, and when it takes place - indeed some of these studies infer learning dynamics from process-tracing (Arrowsmith et al, 2004). 


\section{IDENTIFYING FOUR LEARNING GENERA}

What are the common themes and patterns running through these types? We cannot afford to violate pre-requisites of parsimony and generate a theoretical space with eleven dimensions. Actually, the problem is more serious than a violation of parsimony. From the previous discussion, it is obvious that not all dimensions are on the same level in the proverbial ladder of abstraction (Sartori, 1970). Some are abstract categories, others are more concrete specifications of these categories. Put differently, we have to classify per genus et differentiam in the tradition of Aristotle and (in political science) Sartori. We have to identify the genus first. Then we look at the variation (the differentia) that really matters in order to create the species. Once we understand this pattern, we can correctly classify two studies of the same genus in different species. In qualitative research design, this is equivalent to building an explanatory typology first and then expanding the property space (Elman, 2005). Four genera are proposed below.

1. Arguably, learning as a product of reflexive learning is a major type or genus. Learning is often characterised as 'deep' or 'thick' because it is the major mechanism through which preferences are explored and reinforced. In turn, such explorations bring about the outcomes described by the literature on experimental governance (type g) in the list discussed in section 1), social and deliberative learning (type e), and the discursive-argumentative turn in public policy that emphasizes the transformative potential of framing (type f) Most of this literature has normative assumptions or, at least, shares an interest in identifying the conditions for 'good' or 'participatory' governance. However, scholars working within the advocacy coalitions approach have pinned down the conditions for reflexive learning across coalitions without relying on normative assumptions (Sabatier and Weible, 2007).

2. Let us now consider another of the most important lenses on learning, the epistemic communities tradition. Taken in its broadest sense, this lens covers experts in governments and international organizations, the political role of lawyers and economists in public policy and 'palace wars' (Delazay and Bryant, 2002), the politics of knowledge utilization carried 
out by social and natural scientists for agencies and departments (Boswell, 2008; Author A, 2007, 2009, 2010; Haas, 1992; Stone, 2005; Schrefler, 2010; Stolfi, 2010). Most of this literature revolves around the question whether rationality, science, and experts bring about change in public policy, and if so via what type of instruments, organisational settings, or institutional devices. ${ }^{\text {ii }}$ We have seen that there are different variations within this tradition, but there is no doubt that they have a common core grounded in the notions of communities of experts with shared causal policy beliefs and a paradigm of public policy. It follows that we can start the re-construction of the field with a typology containing epistemic communities as one genus. We also have some expectations that there are species within this genus - as shown by the different declinations of the research on learning and epistemic communities (types a, b and c).

3. Thirdly, we identify the genus of learning as a product of bargaining and social interaction, often as the un-intended product of dense systems of interaction between politicians and bureaucrats (Liberatore, 1999). Three themes in the literature fit this profile - the species of interaction in loosely-coupled organizations and political systems (mentioned under type k), strategic forms of learning (type i), and, arguably, learning 'under conditionality requirements' (type h).

4. When reflexivity is constrained and bargaining limited by strong hierarchical mechanisms we exit the rather pluralistic world of the reflexivity and bargaining genera. We enter a fourth genus characterised by learning in the shadow of hierarchy. There are several characterisations of the shadow (Börzel, 2010; Falkner, 2011 forthcoming; for the original approach see Scharpf, 1988, 1997). But, most of these studies focus on the shadow of organisations/institutions creating pressure to learn (as in type $\mathrm{j}$ ) and/or the shadow of hierarchy where learning is part of a delegation chain (type d).

Explanatory typologies map the variables behind the cells. Having reflected on the four genera, what are the dimensions that shape the four cells? We argue that there are two dimensions 
with which to construct a mutually exclusive and jointly exhaustive explanatory typology. These dimensions are prominent in the literature on social mechanisms and mechanisms of learning (Hedström, 2005; Liberatore, 1999).

The first concerns the level of uncertainty or problem tractability. There is a consistent body of literature in international relations, risk assessment and public policy that points to uncertainty as main discriminatory factor between 'thick' and 'thin' learning, and between processes that can be handled with technical or technocratic approaches and 'contested boundaries' that become ultimately political (Checkel, 1998; Jasanoff, 1987). Think of epistemic communities (Haas, 1992). Absent uncertainty, the epistemic actors have very little to say since elected policymakers and their bureaucracies can calculate the pay-offs of different courses of action (Moravcsik, 1999).

The second is less explicit. Yet, it seems clear that the genera vary in relation to the authority and legitimacy of some key actors or venues. The key question lies in mechanisms of actor's certification. McAdam, Tarrow, and Tilly (2001) have shown that this is a key mechanism of social action. If we 'translate' this key mechanism in the language of learning theory, the issue is whether there is a sort of 'teacher' that can be easily identified by the learners and enjoys some social legitimacy. To illustrate, teachers and narrators can be trusted because they have institutional roles or are endorsed by elected policymakers (Jones and McBeth, 2010). Or we can conjecture that institutional structures provide legitimacy and make a specific teacher heard - or withdraw legitimacy and silence those who speak from outside institutional fora. What was said, and how this is received by the 'pupils', depends on the institutional position of the teacher. Organizational roles and institutional rules and fora are the classic place to look for the mechanisms of an actor's certification. Of course, learning also takes place in 'structureless' environments. For example, the literature on reflexivity does not recognize any ex-ante certification of types of actors - often major innovations come from tapping into the benefits of local knowledge, not 'from the top'. We can also conjecture that there are pluralistic polyarchic settings where no-one is a pre-defined teacher and all actors are virtually able to play the role of learner. In these settings, learning has a relational quality (Fischer, 2003). 
Taken together, the two dimensions provide our basic model of policy learning and four genera (see figure 1).

\section{FIGURE 1 GOES HERE}

\section{EXPANDING THE PROPERTY SPACE}

Typological theory is particularly useful in qualitative studies, but its role is wider since it assists with concept formation, a step that is logically prior to measurement and therefore affects quantitative as well as qualitative studies (George and Bennett, 2005: chpt. 11). There is also a strong connection between the classification steps across the ladder of abstraction and the notion of 'expanding the property space' in typological theory (Elman, 2005), although this connection has not been fully exploited yet. We use the expansion step to highlight the differentia among species. To be 'explanatory', however, a typological expansion has to be grounded in theory. We expand each cell using the findings of education studies of learning as control over knowledge production (Mocker and Spear, 1982, for a political science application of this adult learning typology see Author A, 2009).

Mocker and Spear point to two dimensions: (a) control over the objectives of learning and (b) control over the means and specific content of learning; that is, why one learns and what one learns. Mocker and Spear's typology of adult learning has four types. We use them consistently when we expand the property space. The four types are self-directed learning, informal learning, non-formal learning, and formal learning (see figure 2).

Because their typology is constructed upon empirical reality, as well as theoretical assumptions of intended rationality, Mocker and Spear's descriptions of learning are well-grounded and involve a sufficiently low degree of abstraction that captures specific learning dynamics whose occurrence is 'objectively probable' as opposed to the 'objective possibility' associated with single ideal types ${ }^{\text {iii }}$. 
Self-directed learning is individualized and experiential. Here, learning is unstructured and driven by the learner. With their learning unrestricted by any disciplinary silos or paradigms and predetermined goals, learners enjoy control over all aspects of learning seeking out knowledge from a variety of sources, constructing the problem and establishing their own solutions in their own time; 'learning what they want for as long as they want and stopping when they want' (Rogers, 2004). In its most extreme form, self-directed learning can result in learners both adjudicating and creating evidence rejecting that possibility that any expertise is superior to their own (Rogers, 2002, p.275). More usually, knowledge creation here is not entirely autodidactic, notably learners in the selfdirected mode may take advice from a range of teachers on the veracity of the information they find (Hiemstra, 1994). They do not however identify with a single actor to inform the content and direction of policy. There are no single paradigms or knowledge hierarchies to structure what is learned by policymakers.

Informal learning treats learners as task-conscious. Here learning is not enlightenment for its own sake but rather revolves around assembling the means to dispatch a specific task which has been effectively set for them (Rogers, 2003, pp.18-21). While the learner directs the selection and production of substantive resources, the presence of externally determined policy goals bound this scope for choice; the development of 'know-how' requires that learners are conscious of extrinsic evaluation where the substantive arguments they amass will be assessed in terms of goals that are determined by other actors.

Formal learning refers to externally imposed learning where the learner's control over both the substantive content of knowledge and ends to which it is applied is severely constrained (Coombs and Ahmed, 1974). Learning here takes the form of guided episodes from teacher to learner where there is acceptance on both sides that learning needs to occur (Rogers, 2002, p.279).

Non-formal learning refers to situations where information is moulded to learners' own circumstances and the teacher's role is that of facilitator. Here, learners' awareness of what they want to do with what they learn ensures that their engagement with codified knowledge is mediated by pre- 
existing expectations for determining the use or success of that knowledge (Heimlich, 1993; Tough, 1971). For non-formal learning to be identified, evidence is required of decision-makers' dependence on, for example, epistemic communities for the delivery, legitimization or justification policy preferences that have been formed independently of their relationship with these experts.

\section{FIGURE 2 GOES HERE}

By using control over the contents of learning and control over the goals of learning we can then generate four cells out of each cell of the basic model of figure 1. This is the step of "expanding the property space' (Elman, 2005). By way of expansion, we create sixteen species out of the four genera. The fact that we have started with a loose map of eleven species and we end up with sixteen simply means that some species, although conceptually possible, have not been empirically found yet (or we have not been able to find the articles that clearly map onto them). This way we systematize what is already known and also show the territory that is empirical possible, if as yet unexplored.

There is yet another benefit in the expansion of the property space. The expansion shows the variability within the four genera. Instead of treating reflexivity, epistemic communities, bargaining and 'the shadow' as monoliths, we explore the scope conditions for them to occur and the nuances possible within a single genus.

\section{a) Reflexive Learning}

We first expand the cells of the reflexive learning genus, using figure 3. Recall that, for reflexive learning to occur, uncertainty has to be high and the certification of specific actors low. In this genus or type (that is, reflexive learning) the classic distinction between learner and teacher does not make sense. There is no pre-identified hierarchical role in terms of learning and no presupposition about who should learn from whom. Learning is the outcome of a social relation within a community of 
actors or a network (see Freeman 2006 on the difference between the two). Institutions do not set hierarchical rules for the production and utilization of knowledge.

The distribution of power is polyarchic, and there has to be room for force-free deliberation, at least in the pure type discussed by the literature on reflective social governance. Preferences can change as a result of communicative rationality. There is no ex-ante hypothesis about where the seeds of learning may germinate (lay knowledge is as important as professional and expert knowledge for reflexive dynamics to occur). The major problem is how to diffuse innovation and the seeds of learning across the community or network that is engaged with learning. This is why reflexive learning is often accompanied by governance architectures that facilitate the exploitation of this type of learning (Sabel and Zeitlin, 2008, for example refer to architectures of facilitated coordination).

\section{FIGURE 3 GOES HERE}

Deliberation (type e) of the eleven discussed in section 1) is arguably the most classic form of reflexivity (it is bold and underlined in figure 3); learning is not deduction, but the outcome of a process of communication, persuasion, and invention. The constellation of actors is, as it were, its own principal. It can pursue enlightenment for its own sake. It can reflexively modify preferences without exogenous constraints. Since preferences can change, the objectives of learning are dynamic and endogenous to the process of social interaction. In this specification, 'policy' is not something 'finished' out there that has to be learned by the constellation of actors (Freeman, 2006). Policy, instead, is finished and, even produced, in the act of learning.

Reflexivity is constrained in experimental learning (type g). There cannot be enlightenment for its own sake but rather is bound up with the ideal of democratic polyarchies. Reflexivity is anchored to the task set for the community of learners - the task or end is exogenous. However, the constellation of actors has control over the means and contents of what is being learned. We can think of experimental processes of trial-and-error with different forms of know-how and policy instruments, where Bayesian learning leads to the type of content that best suits the exogenous learning goal. 
In framing (type f) the learning experience is contingent on how the learners frame their problem. Since they have no control over the means and content of learning, the learning experience will operate through issue framing in the context of a given over-arching goal. Framing in the context of exogenous objectives can also lead to learning as delivery, legitimation, and justification. Reflexivity can also fail and produce zero learning if the mechanisms of learning do not fit with the pre-existing objectives of learning - put differently, there may be mismatch.

Though we did not identify it in our trawl of the literature on policy learning, a fourth conceptually possible species is highlighted by the expansion. Where learning is evolutionary, it takes place in communities or networks where there are no pre-defined teachers. Learning has to occur on all sides since the objectives are pre-determined exogenously. Reflexivity is limited or bound because the objectives of learning are not controlled by the constellation of actors. The constellation has another limitation: it cannot control the means and contents of learning. We are therefore reducing the scope of reflexivity to its minimal properties. We can think of evolutionary mechanisms that force the community/network of actors to learn - otherwise they do not survive. Although constrained, the actors can still be reflexive and modify their preferences to avoid what for them is a doomsday scenario.

\section{b) Epistemic Communities}

Let us move to the species in the epistemic community genus in figure 4. Recall that we need high actor certification and low problem tractability for this genus to operate. By expanding the property space, we find a classic (for this literature) species of formal learning (it is bold and underlined in figure 4, called 'expert as teacher') and three other species.

'Expert as teacher' (type a) of our eleven) is classic in that, the literature on epistemic communities has implicitly identified this as the ideal-typical form epistemic learning (Haas, 1992). Since epistemic actors are socially certified teachers, or there are characteristics of the venue that produce certification (such as mandatory consultation of experts before decisions are taken or 
delegation of power to expert's committees), we have a clear teacher-learner relation. The epistemic community assumes the role of teacher and provides both the broad ends of the learning exercise and the substantive means (Author A, 2009, p.292). This way, epistemic communities reduce uncertainty and contribute to the definition of actor's interests.

\section{FIGURE 4 GOES HERE}

At the opposite, we find the 'agent' as the weakest species in the genus of epistemic learning (type c). In this specification, policymakers are the principal. The epistemic actors are agents - they are effectively controlled by their principals (see Author A, 2010). The scientist, or more generally the epistemic actor, is an efficiency device in that this actor reduces the information deficit of the principal. Here the teacher is very much piloted by the learner, and this also affects the modalities of knowledge utilization; only knowledge that is directly useful to the principal is used. Learning is directed and intentional.

Next we have the 'facilitator' (type b). In this species, learners use their teachers to facilitate their process of learning. The epistemic actors are facilitators; they do not contribute to the definition of the interests of the learner. The learner engages with the teacher and learns, but knowledge utilization is subordinate to a context of pre-determined expectations set by the teacher. Think of a pre-determined goal to use knowledge about public expenditure produced by a new monitoring system of public accounts to reduce the overall public budget for the next year.

The last quadrant we examine in figure 3 is the producer of know-how. This is the conceptual 'dark side' of epistemic communities - as yet empirically unexplored. Here the learner organizes the production and selection of knowledge. However, there are learning objectives that are determined exogenously. It follows that knowledge production and utilization will be assessed in terms of objectives that are determined outside the relationship between the teacher and the learner. For example, a department or public organization sets up mechanisms of knowledge production by experts committees, but in the presence of an exogenous political objective such as a coalition 
agreement to introduce rights for migrant workers. The essence of the learning experience is about producing technical know-how that can fit in with the pre-existing objectives.

\section{c) Bargaining}

Turning to bargaining, this genus has high problem tractability and low or no actors' certification. Bargaining produces learning as the un-intended product of political competition and negotiations as in Lindblom's partisan mutual adjustment. Yet again, we do not have neat separation between the teacher and the learner (low actor's certification). The tractability of the problem (low uncertainty) facilitates bargaining and strategic interaction since the pay-offs of different moves can be calculated by actors whose preferences do not change.

\section{FIGURE 5 GOES HERE}

We mention that it is conventional to think of the Lindblomian notion of the intelligence of democracy (Lindblom, 1965) as the ideal-typical manifestation of bargaining approaches to learning (though empirically we could find no studies where partisan mutual adjustment is the key mechanism of learning).

Moving to the next species - conditionality (type h) of our eleven) - we find a degree of coercion to meet certain objectives of learning - which are determined exogenously. Actors bargain to meet standards and targets, and in doing so, they informally encounter learning in the shape of know-how and possibly discover smarter policymaking procedures or instruments. One way this may happen is when actors are pressured by conditionality requirements - the literature has shown that 'smart' and 'clever' solutions are facilitated by the imperatives of conditionality. Learning under conditionality can also help actors to get smarter in another way, that is, to get around the formal conditionality requirements and 'use' standards and targets to their benefit. 
The next cell is loosely-coupled learning (type k). There are no pre-defined teachers and learners - the model is contingent on a pluralist vision of the policy process where $\mathrm{n}$ actors interact with given preferences. The actors do not control the objectives of learning. Neither do they control the contents and means of learning. They interact and encounter learning in a very un-structured or loosely coupled format. It is difficult to predict how learning can occur, and when it takes place. Here, instances of failed learning (failure to use bargaining to learn) will be common, as well as episodes of un-intended learning (Liberatore, 1999).

The fourth bargaining species involves a strategic approach to learning (type i). The constellation of actors do not exercise control over the means of learning, thus there will be a certain degree of improvisation in this learning process. Bargaining can show how to acquire know-how, or it can produce failed learning. This, however, does not mean that the trajectory of learning is confused. The actors involved in the process can set their own goals - they are strategic about where they want to go with their learning process.

\section{d) The "Shadow"}

The 'shadow' is our last genus to be expanded into four cells (figure 6). High problem tractability (low uncertainty) and high certification of actors or/and venues characterize the shadow. As mentioned, the original intuition of the shadow was linked to the problem-solving bottlenecks of German federalism and the European Community of the 1970s, as examined by Scharpf (1988). The idea is that interaction in complex systems with multiple veto-players creates 'joint-decision trap' blockages. However, the presence of default conditions (that is, what happens if agreement is not found) generates agreement under certain conditions. To illustrate, within a given system of interaction, the actors may learn that their default condition is the intervention of a hierarchical, irreversible decision by a Court (Schmidt, 2000). This kind of Damocles' sword alters the attitude of governments in the EU Council to the point of overcoming joint-decision traps, especially if the threat of the Court is brought about by purposeful bureaucratic actors like the European Commission (Schmidt, 2000). 
The 'shadow' is not necessarily produced by a Court. We can think more generally of political institutions that when present, alter the default condition with their rules, codes of behaviour, memories and organizational logic. Institutions can either provide 'rules of the game' (in the sense of the rational-choice version of the shadow articulated by Scharpf) or codes, identities, collective memories, lock-in mechanisms and roles that also alter the default condition, but through the logic of appropriateness of organizational sociology.

Thus, in contrast to the large (rational-choice inspired) majority of the work on the shadow (for the different approaches see Héritier and Rhodes, 2010; Falkner, 2011), there is room for a sociological version. We do not make distinctions between sociological or rational choice understandings of institutions here, since the emphasis is on the properties of social interactions. Neither do we distinguish between acting in the shadow of hierarchy or within hierarchy, since the implications for our typological exercise are the same.

What about learners and teachers under the shadow? There is a kind of teacher-learner relationship but this has less to do with specific actors (such as the experts, the scientists etc) and more with the content of institutional rules. Institutions 'teach' roles via socialization and/or are channels through which rules are taught to the actors in the system of interaction.

\section{FIGURE 6 GOES HERE}

This is the genus whose expansion requires most imagination: indeed, two of the four 'shadows' are conceptually possible but not empirically demonstrable from our review of the literature.

But, let's start with a species we have found. Where learning is instrumental (type j) of our eleven), learners operate within exogenous objectives of learning, but they do control the means and content of learning. The shadow provides clues on what to do with learning. It structures interaction among learners. There is pressure to learn (in turn, pressure can come from the organization, political competition in government, elections, and so on) but the logic of discovery is relatively free in 
relation to the means and content. This should facilitate instrumental learning and marginal improvement at the level of the tools of government and the instruments of public policy.

The second species we found is that of delegation (type d). Here, learners set their learning objectives autonomously, but are constrained as to the contents and means of learning. Here the shadow can be a resource used to organize the production and dissemination of knowledge. The vast literature on principal-agent models has show different ways in which knowledge production, utilization and diffusion can be organized along a chain of delegation of tasks. The learners design the tasks by remaining in control of the objectives of learning.

And now, to the dark sides. We propose the idea of 'hetero-directed learning' as the idealtypical or classic way of thinking about the shadow (bottom-right quadrant in figure 6) since it typifies the essence of steering. Learners are entirely driven by the shadow since they cannot control either the means of learning or the objectives. This type of severely bound learning takes place in highly institutionalized environments. Learning is reduced to coping with instructions; a type of learning by rote about procedures, roles, and memorizing of doing things.

Autonomy is almost antithetical to the essence of hierarchy represented by the 'heterodirected' cell. Indeed, 'autonomy' is the weakest specification ever possible of any shadow. True, we assume that the learners still operate within the shadow - think of domestic policymakers implementing EU directives in the shadow of Community law. But they can decide autonomously what they want to learn and how. To continue with the example, they can try to learn how not to goldplate directives and which regulatory instruments to use in implementation. It is almost an 'escape from hierarchy' scenario where the learners are relatively autonomous in a given structure of authority. The essence of learning is about carving out spaces for experimentation and genuine discovery.

\section{DISCUSSION}


What do we gain from the typological exercise, then? What does it really 'show'? How can it be used? To begin with, let us think of the typology in the same way we approach hypertexts. At the most abstract level, we have four concepts that typify how political scientists have approached the study of learning: they are reflexivity, the epistemic school, the bargaining-pluralist approach, and institutional or rule-based modes of analysis. This is a broad map that sheds light on how the various schools of thought approach learning from radically different assumptions concerning preference formation, hierarchy, and the ontological question of whether learning is an asymmetric relation between teachers of pupils or a highly interactive process. Further, it is obvious that whilst some look at macro processes involving negotiations among states or broad trends in policy convergence, others deal with micro processes, organizations, and communities of policy makers (Zito and Schout, 2009b, pp.1103).

Thus, at this abstract level, the map can be used to generate meta-theories of policy learning. Meta-theory is concerned with the sociology of knowledge, the ontological dimension of theories, and the core epistemological propositions. Applied to policy learning, a meta-theoretical approach exposes the different ontological assumptions and the core epistemological beliefs of different social scientists engaged with learning in public policy. It shows why and how different areas of the discipline are genuinely after 'different things' because of their understandings of the social and political worlds. Within the higher-level map, propositions such as 'learning contrasts with rational policy theories in which optimal policy conclusions are derived from static analysis' (Zito and Schout, 2009b, pp.1104) do not make sense, since we can produce rational-choice learning theories derived from an ontology that is social (meaning that the policy objects are socially constructed via meanings attached to events and problems) and an epistemology that is objective, but accounts for information that is costly.

To proceed with the metaphor of the hypertext, we can then metaphorically click on any of the four concepts and find more detail when we expand the property space. Here our major finding is to show bias in what has been done until now. Most of the research has gone in some cells but others have been neglected. Yet all the cells, from the point of view of pure logic, have the same status and deserve the same attention. It follows that there are areas were we need to drill more, such as the cells of the 'producer of know how', 'intelligence of democracy', 'evolutionary patterns of learning', and 
the odd but potentially intriguing cells of 'autonomy', and 'hetero-directed' learning. At the opposite side of the spectrum, we find cells such as 'delegation' and 'deliberative' learning that are never short of scholarly attention. In brief, the typological exercise shows where high-risk but potentially rewarding investment of research time and energy should be made. It also shows how some fields in the discipline of learning navigate pretty well across the cells. Arguably the best example is the literature on policy diffusion, which, depending on the emphasis on herding or strategic behavior, can be classified in one cell or another. For diffusion scholars, our exercise is relevant because it makes clear how different studies have refracted the phenomenon of diffusion by using alternatives conceptualizations of learning, and ultimately have generated different results.

\section{CONCLUSIONS}

Scholars working on learning tend to talk past each other because they do not realize the difference between genus and species; because they do not see the variables that connect one type to others; and because they measure learning with different types of bias (Author B, 2009). This article has illustrated the relationships between the genera in the basic model of policy learning, and expanded the property space by showing different characterisations of the individual species. As a result, we reveal that concepts such as 'reflexive learning' and 'epistemic communities' are not monoliths: they can be disaggregated to make them amenable to fine-grained empirical analysis. Classificatory analysis provides maps and toolboxes, and clarifies concepts that are often confused.

We proceeded by combining the classic Sartorian approach to classification with explanatory typologies. This blend has enabled us to find different mechanisms and relations associated with alternatives operationalizations of learning and the role of actors in the process of knowledge construction and utilization. In this way, we hope to show how the field of policy learning can be usefully reconstructed and analysis ordered. The aim of this exercise is to lay the foundations for the systematic comparison across and within cases. 
Another result was to make explicit the theoretical assumptions we make when we move from one genus to others. Our preference is for theories of knowledge utilization, and for a blend of politics and sociology on one hand, and the education literature on the other. We have said that the choice of looking at knowledge utilization is an asset, but for other researchers this might be a liability since it narrows down learning to specific processes involving knowledge. Future research may well question our theoretical choice, and move from different frameworks to map learning. Another possible avenue for future research is to move towards empirical exploration of processes and mechanisms, and establish whether a given policy domain can move from one cell to another, and if so why. This will also enable researchers to make sense of the different roles of agency and structure in the dynamics of learning. Finally, there are possible normative explorations of our types. Given a constellation of actors and problems in a policy domain, what is the most appropriate type of learning? Policy designers may use our explanatory typologies to try to move a given constellation from 'experimental' to 'evolutionary', or insert doses of 'shadow of hierarchy' to obtain certain outcomes ${ }^{\text {iv }}$

\section{REFERENCES}

Arrowsmith, J., Sisson, K., and Marginson, P. (2004) 'What can "Benchmarking" Offer the Open Method of Coordination?', Journal of European Public Policy, 11 (2), 311-328.

Author, A (2009)

Author, A. (2007)

Author, A. (2010)

Author, A. and colleague (2007)

Author, B. (2004)

Author, B. (2009)

Barzelay, M. (2007) 'Learning from Second-Hand Experience: Methodology for ExtrapolationOriented Case Research", Governance 20 (3), 521-543.

Börzel, T. (2010) 'European Governance: Negotiation and Competition in the Shadow of Hierarchy', Journal of Common Market Studies, 48 (2): 191-219.

Boswell C. (2008) 'The Political Functions of Expert Knowledge: Knowledge and Legitimation in European Union Immigration Policy', Journal of European Public Policy, 15 (4), 471-88. 
Checkel, J. (1998) 'The Constructivist Turn in International Relations Theory', World Politics, 50 (2), 324-348.

Collier, D., Laporte, J. and Seawright, J. (2008) 'Typologies: Forming Concepts and Creating Categorical Variables', in Box-Steffensmeier, J.M., Brady, H.E. and Collier, D. (eds) The Oxford Handbook of Political Methodology. Oxford: Oxford University Press.

Coombs, P.H. and Ahmed, M. (1974) Attacking Rural Poverty. Baltimore, MD: John Hopkins University Press.

Cram, L. (1993) 'Calling the Tune without Paying the Piper? Social Policy Regulation: the Role of the Commission in European Community Social Policy', Policy and Politics, 21 (1), 135-146.

Daviter, F. (2007) 'Policy Framing in the European Union', Journal of European Public Policy, 14 (4), 654-666.

Delazay, Y. and Bryant, G.G. (2002) The Internationalization of Palace Wars: Lawyers, Economists, and the Contest to Transform Latin American States. Chicago: University of Chicago Press.

Denzau, A.D. and North, D.C. (1994) 'Shared Mental Models: Ideologies and Institutions', Kyklos 47 (1), 3-31.

Deutsch, K.W. (1966) The Nerves of Government. New York, NY: The Free Press.

Dobbin, F., Simmons, B.A. and Garrett, G. (2007) 'The Global Diffusion of Public Policies: Social Construction, Coercion, Competition, or Learning?', Annual Review of Sociology, 33, 449472 .

Dolowitz, D. (1997) 'British Employment Policy in the 1980s: Learning from the American Experience', Governance, 10 (1), 23-42

Dolowitz, D. (2009) 'Policy Transfer: A Re-Assessment', Policy and Politics, 37 (3), Special issue.

Dolowitz, D. and Marsh, D. (1996) 'Who Learns What From Whom: A Review of the Policy Transfer Literature', Political Studies, 44 (2), 343-357.

Egan, M. (2009) 'Governance and Learning in the Post-Maastricht Era?', Journal of European Public Policy 16 (8), 1244-1253.

Eising, R. (2002) 'Policy Learning in Embedded Negotiations: Explaining EU Electricity Liberalization', International Organization, 56 (1), 85-120.

Elgström, O. and Jönsson, C. (2000) 'Negotiation in the European Union: Bargaining or Problemsolving?', Journal of European Public Policy, 7 (5), 684-704.

Elman, C. (2005) 'Explanatory Typologies in Qualitative Studies of International Politics' International Organization, 59 (2), 293-326.

Evans, M. (2009) 'Policy Transfer in Critical Perspective', Policy Studies, 30 (3), 243-268.

Falkner, G. (2011) (ed.) The EU's Decision Traps: Comparing Policies. Oxford: Oxford University Press.

Fischer, F. (2003) Reframing Public Policy: Discursive Politics and Deliberative Practices. Oxford: Oxford University Press. 
Freeman, R. (2006) 'Learning in Public Policy', in Moran, M., Rein, M. and Goodin, R.E. (eds.) Oxford Handbook of Public Policy. Oxford: Oxford University Press.

Freeman, R. (2007) 'Epistemological Bricolage', Administration and Society, 39, 476-496.

George, A. L., and Bennett, A. (2005) Case Studies and Theory Development in the Social Sciences. Cambridge: MIT Press.

Gerstenberg, O. and Sabel, C.F. (2002) 'Directly-Deliberative Polyarchy: An Institutional Ideal for Europe? in C. Joerges and R. Dehousse (eds.) Good Governance in Europe's Integrated Markets. Oxford: Oxford University Press, pp. 289-341.

Gilardi, F. (2008) Delegation in the Regulatory State: Independent Regulatory Agencies in Western Europe. Cheltenham: Edward Elgar.

Gilardi, F. (2010) 'Who Learns from What in Policy Diffusion Processes?', American Journal of Political Science, 54 (3), 650-666.

Graham, E., Shipan, C. and Volden, C. (2008) 'The Diffusion of Policy Diffusion Research', paper presented at APSA Annual Meeting, Boston 28 August.

Grin, J. and Loeber, A. (2007) 'Theories of Policy Learning: Agency, Structure and Change', in Fischer, F., Miller, G.J. and Sidney, M.S. (eds) Handbook of Public Policy Analysis. Boca Raton, FL: CRC Press.

Grin, J., and van de Graaf, H. (1996) 'Implementation as Communicative Action - An Interpretive Understanding of Interactions Between Policy Actors and Target Groups', Policy Sciences, 29 (4), 291-319.

Grossback, L.J., Nicholson-Crotty, S. and Peterson, D.A.M (2004) 'Ideology and Learning in Policy Diffusion', American Politics Research, 32 (5), 521-545.

Haas, P.M. (1992) 'Introduction: Epistemic Communities and International Policy Coordination', International Organization, 46 (1), 1-36.

Hall, P.A. (1993) 'Policy Paradigms, Social Learning and the State: The Case of Economic Policymaking in Britain', Comparative Politics, 25 (3), 275-296.

Heclo, H. (1974) Modern Social Politics in Britain and Sweden. New Haven, CT: Yale University Press.

Hedström, P. (2005) Dissecting the Social: On the Principles of Analytical Sociology. Cambridge: Cambridge University Press.

Heimlich, J. (ed). (1993) Nonformal Environmental Education: Toward a Working Definition Information Bulletin 502E, Columbus, OH: ERIC.

Héritier, A. and Rhodes, M. (eds.). (2010) New Modes of Governance in Europe: Governing in the Shadow of Hierarchy. Houndmills: Palgrave MacMillan.

Hiemstra, R. (1994) 'Self-Directed Learning' in T. Husen and T.N. Postlethwaite (eds) The International Encyclopedia of Education. Oxford: Pergamon Press.

James, O. and Lodge, M. (2003) 'The Limitations of 'Policy Transfer' and 'Lesson Drawing' for Public Policy Research', Political Studies Review, 1 (2), 179-93. 
Jasanoff, S. (1987) 'Contested Boundaries in Policy-Relevant Science', Social Studies of Science, 17 (2), 195-230.

Jones, M.D., and McBeth, M.K. (2010) 'A Narrative Policy Framework: Clear Enough to Be Wrong?’, Policy Studies Journal, 38 (2), 329-353.

Jordan, A. and Greenaway, J. (1998) 'Shifting Agendas, Changing Regulatory Structures and the 'New' Politics of Environmental Pollution', Public Administration, 76 (4), 669-694.

Lenoble, J., and De Schutter, O. (eds) (2010) Reflexive Governance: Redefining the Public Interest in a Pluralistic World. Oxford: Hart.

Liberatore, A. (1999) The Management of Uncertainty: Learning from Chernobyl. Amsterdam: Gordon and Breach Publishers.

Lindblom, C.E. (1959) 'The Science of Muddling Through', Public Administration, 19, 78-88.

Lindblom, C.E. (1965) The Intelligence of Democracy. New York NY: The Free Press.

Lindquist, E.A. (1992) 'Public Managers and Policy Communities: Learning to Meet New Challenges', Canadian Public Administration, 35 (2).127-159.

Lindquist, E.A. (1992) 'Think Tanks or Clubs? Assessing the Influence and Roles of Canadian Policy Institutes', Canadian Public Administration 34 (4), 54-579.

McAdam, D., Tarrow, S. and Tilly, C. (2001) Dynamics of Contention. Cambridge, Cambridge University Press.

McKinney, J.C. (1966) Constructive Typology and Social Theory. New York, NY: Meredith.

Meseguer, C. (2005) 'Policy Learning, Policy Diffusion, and the Making of a New Order', Annals, AAPSS 598 (March), 67-82.

Meseguer, C. (2009) Learning, Policy Making and Market Reforms. Cambridge: Cambridge University Press.

Meseguer, C. and Escribà-Folch, A. (2011) 'Learning, Political Regimes and the Liberalization of Trade', European Journal of Political Research, in press. [Accessed in early view]

Mocker, D.W., and Spear, G.E. (1982) Lifelong Learning: Formal, Nonformal, Informal, and SelfDirected. Information Series No. 241, Columbus, Ohio: ERIC.

Moravcsik, A. (1999) 'A New Statecraft? Supranational Entrepreneurs and International Cooperation' International Organization, 53 (2), 267-306.

Moynihan, D.P. (2005) 'Why and How Do State Governments Adopt and Implement "Managing for Results" Reforms?', Journal of Public Administration Research and Theory, 15 (2), 219-243.

Olsen, J.P., and Peters, G.B. (eds) (1996) Lessons from Experience. Experiential Learning in Administrative Reforms in Eight Democracies. Oslo: Scandinavian University Press.

Rogers, A. (2002) [1986] Teaching Adults. $3^{\text {rd }}$ edn Maidenhead: Open University Press.

Rogers, A. (2003) What is the Difference? Leicester: NIACE. 
Rogers, A. (2004) Non-Formal Education: Flexible Schooling or Participatory Education? Dortrecht: Kluwer.

Rose, R. (1991) 'What is Lesson-Drawing?', Journal of Public Policy 11 (1), 3-30.

Rowe, R. and Shepherd, M. (2002) 'Public Participation in the New NHS: No Closer to Citizen Control?', Social Policy and Administration, 36 (3), 275-290.

Sabatier, P.A. and Weible, C.M. (2007) 'The Advocacy Coalition Framework: Innovations and Clarifications' in P.A. Sabatier (ed) Theories of the Policy Process. Boulder, CO: Westview Press, pp. 189-220.

Sabatier, P.A. and Jenkins-Smith, H.C. (1993) Policy Change and Learning. An Advocacy Coalition Approach. Boulder, CO: Westview Press.

Sabel, C., and Zeitlin, J. (2008) 'Learning from Difference: The New Architecture of Experimentalist Governance in the European Union', European Law Journal, 14 (3), 271-327.

Sanderson, I. (2002) 'Evaluation, Policy Learning and Evidence-Based Policy Making', Public Administration, 80 (1), 1-22.

Sanderson, I. (2009) 'Intelligent Policy Making for a Complex World: Pragmatism, Evidence and Learning', Political Studies, 57 (4), 699-719.

Sartori, G. (1970) 'Concept Misformation in Comparative Politics', American Political Science Review, 64 (4), 1033-1053.

Schäfer, A. (2006) 'A New Form of Governance? Comparing the Open Method of Co-ordination to Multilateral Surveillance by the IMF and the OECD', Journal of European Public Policy, 13 (1), 70-88.

Scharpf, F. (1988) ‘The Joint Decision Trap’, Public Administration, 66 (3), 239-278.

Scharpf, F. (1997) Games Real Actors Play. Actor-Centered Institutionalism in Policy Research. Boulder, CO: Westview.

Schlager, E. (1997) 'A Response to Kim Quaile Hill's In Search of Policy Theory', Policy Currents, 7, 14-15.

Schmidt, S.K. (2000) 'Only an Agenda Setter? The European Commission's Power Over the Council of Ministers', European Union Politics, 1 (1), 37-61.

Schmidt, V.A. (2002) 'Does Discourse Matter in the Politics of Welfare State Adjustment?', Comparative Political Studies, 35 (2), 168-193.

Schrefler, L. (2010) 'The Usage of Scientific Knowledge by Independent Regulatory Agencies', Governance, 23 (2), 309-330.

Simon, H. (1947) Administrative Behavior: a Study of Decision-Making Processes in Administrative Organization. New York, NY: The Free Press.

Simon, H. (1957) Models of Man. New York, NY: Wiley.

Smith, K.B. (2002) 'Typologies, Taxonomies, and the Benefits of Policy Classification', Policy Studies Journal, 30 (3), 379-395. 
Stolfi, F. (2010) Testing Structuralist and Interpretative Explanations of Policy Change: The Case of Italy's Budget Reform', Governance, 23 (1), 109-132.

Stone, D. (2005) 'Knowledge Networks and Global Policy', in D. Stone and S. Maxwell (eds) Global Knowledge Networks and International Development. London: Routledge.

Stone, D., Garnett, M., and Denham, A. (eds) (1998) Think Tanks Across the World. A Comparative Perspective. Manchester: Manchester University Press.

Thatcher, M. and Sweet, A.S. (2002) 'Theory and Practice of Delegation to Non-Majoritarian Institutions', West European Politics, 25 (1), 1-22.

Tough, A. (1971) The Adult's Learning Projects. Toronto: Ontario Institute for Studies in Education.

Volden, C., Ting, M.M. and Carpenter, D.P. (2008) 'A Formal Model of Learning and Policy Diffusion', American Political Science Review, 102 (3), 319-332.

Waterman, R.H., and Meier, K.J. (1998) 'Principal-Agent Models: An Expansion?', Journal of Public Administration Research and Theory, 8 (2), 173-202.

Weisband, E. (2000) 'Discursive Multilateralism. Global Benchmarks, Shame, and Learning in the ILO Labour Standards Monitoring Regime', International Studies Quarterly, 44, 643-666.

Weyland, K. (2005) 'Theories of Policy Diffusion - Lessons from Latin American Pension Reform' World Politics, 57 (2), 262-295.

Zito, A.R. and Schout, A. (eds) (2009a) Learning and Governance in the EU Policy-Making Process, special issue Journal of European Public Policy, 16 (8), 1103-1253.

Zito, A.R. and Schout, A. (2009b) 'Learning Theories Reconsidered: EU Integration Theories and Learning', Journal of European Public Policy, 16 (8), 1103-1123.

\footnotetext{
${ }^{i}$ We searched in the ISI Social Science Citation index on 16 May 2011 with the following criteria: Topic=(Policy learning) OR Topic $=($ organizational learning) OR Topic $=($ social learning $)$ AND TOPIC $=($ Public Policy $)$ AND Topic $=($ Learning $)$. We then refined by subject areas International Relations OR Public Administration OR Political Science OR Law OR Sociology OR Urban Studies. This produced an initial sample of 833 articles. 730 articles were rejected from this sample through a search for duplicates (26), low citation counts (5 and under, 430) and two abstract sifts (270 and 31 articles were rejected respectively). The main reasons for the rejection of nonduplicated papers were papers that focused on learning between non-state actors or actors outwith the political sphere; those which used the term learning in a purely descriptive way; those for whom 'more' or 'better' learning was a prescriptive punchline, and finally, those studies which reviewed the literature without attempting to conceptualise or systematise it. Of the remaining 103 articles a further 8 were rejected and 9 were not available in their full form. This left us with a sample of 86 articles that could be explored.

ii The advocacy coalition scholars (Sabatier and Weible, 2007) refer to some of the core propositions on this literature. Yet they examine experts and scientists within coalitions and processes of knowledge utilization.

iii See McKinney, 1966: chapter 2 for a comparison of ideal types and constructed typologies and Smith, 2002 for a comparison of
empirically based and conceptually inspired typologies. ${ }^{\text {iv }}$ We thank XXX for making this point to us.
} 